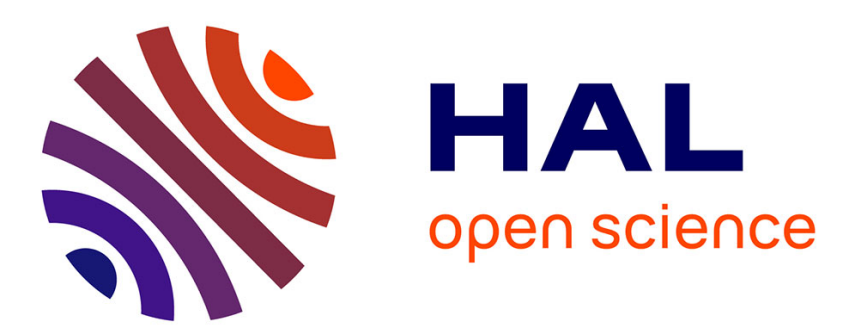

\title{
Preparation and mechanical characterisation of laminate composites made of glass fibre/epoxy resin filled with tri bloc copolymers
}

Rodrigue Matadi Boumbimba, Catherine Froustey, Philippe Viot, J.-M. Olive, Frédéric Léonardi, Pierre Gerard, Raber Inoubli

\section{To cite this version:}

Rodrigue Matadi Boumbimba, Catherine Froustey, Philippe Viot, J.-M. Olive, Frédéric Léonardi, et al.. Preparation and mechanical characterisation of laminate composites made of glass fibre/epoxy resin filled with tri bloc copolymers. Composite Structures, 2014, 116, pp.414-422. 10.1016/j.compstruct.2014.05.028 . hal-02910333

\section{HAL Id: hal-02910333 \\ https://hal.science/hal-02910333}

Submitted on 1 Aug 2020

HAL is a multi-disciplinary open access archive for the deposit and dissemination of scientific research documents, whether they are published or not. The documents may come from teaching and research institutions in France or abroad, or from public or private research centers.
L'archive ouverte pluridisciplinaire HAL, est destinée au dépôt et à la diffusion de documents scientifiques de niveau recherche, publiés ou non, émanant des établissements d'enseignement et de recherche français ou étrangers, des laboratoires publics ou privés. 


\section{Preparation and mechanical characterisation of laminate composites made of glass fibre/epoxy resin filled with tri bloc copolymers}

Rodrigue Matadi Boumbimba, Catherine Froustey, Philippe Viot, Jean -Marc Olive, Frédéric Léonardi, Pierre Gerard, Raber Inoubli

\section{To cite this version:}

Rodrigue Matadi Boumbimba, Catherine Froustey, Philippe Viot, Jean -Marc et al.. Preparation and mechanical characterisation of laminate composites made of glass fibre/epoxy resin filled with tri bloc copolymers. Composite Structures, Elsevier, 2014, 116, pp.414-422. hal02308308

\section{HAL Id: hal-02308308 \\ https://hal.archives-ouvertes.fr/hal-02308308}

Submitted on 8 Oct 2019

HAL is a multi-disciplinary open access archive for the deposit and dissemination of scientific research documents, whether they are published or not. The documents may come from teaching and research institutions in France or abroad, or from public or private research centers.
L'archive ouverte pluridisciplinaire HAL, est destinée au dépôt et à la diffusion de documents scientifiques de niveau recherche, publiés ou non, émanant des établissements d'enseignement et de recherche français ou étrangers, des laboratoires publics ou privés. 


\title{
Preparation and mechanical characterisation of laminate composites made of glass fibre/epoxy resin filled with tri bloc copolymers
}

\author{
R. Matadi Boumbimba ${ }^{\mathrm{a}, *}$, C. Froustey ${ }^{\mathrm{b}}$, P. Viot ${ }^{\mathrm{a}}$, J.M. Olive ${ }^{\mathrm{c}}$, F. Léonardi ${ }^{\mathrm{d}}$, P. Gerard ${ }^{\mathrm{e}}$, R. Inoubli ${ }^{\mathrm{e}}$
}

\author{
${ }^{a}$ Arts et Métiers Paristech, I2M, UMR CNRS 5295, F-33405 Talence, France \\ ${ }^{\mathrm{b}}$ Université Bordeaux, I2M, UMR CNRS 5295, F-33405 Talence, France \\ ${ }^{\text {c } C N R S, ~ I 2 M, ~ U M R ~ 5295, ~} 33405$ Talence, France \\ d IPREM - EPCP - CNRS UMR 5254, Hélioparc Pau Pyrénées, F-64053 Pau, France \\ e ARKEMA, Groupement de Recherche de Lacq, F-64170 Lacq, France
}

\section{A R T I C L E I N F O}

\section{Article history:}

Available online 3 June 2014

\section{Keywords:}

Glass fibres

Hybrid composites

Impact behaviour

Dynamic mechanical thermal analysis (DMTA)

\begin{abstract}
A B S T R A C T
Laminate composites made of glass fibre/epoxy resin filled with acrylic tri-bloc copolymers (Nanostrength) have been successfully manufactured. Microstructure, thermomechanical properties and impact resistance have been investigated and compared with those of a glass fibre/epoxy resin system. Dynamic mechanical analysis (DMA) tests have been conducted to determine the effect of Nanostrength on storage, loss modulus and glass transition temperature. A drop weight tower was used to perform low-velocity impact tests on laminate composites. Addition of Nanostrength to the epoxy matrix led to an increase in both strength and impact resistance of the composite. Moreover, a moderate decrease of storage modulus and glass transition temperature was observed.
\end{abstract}

\section{Introduction}

Polymer composites reinforced with long fibres are widely used as high-performance materials in various industries such as automotive, rail-industry, aerospace, sport and civil engineering. These materials become very suitable for all applications which require high strength and low weight. Among thermosetting polymers used in composites manufacturing, epoxy resins are the most widely used for high performance applications [1]. Epoxy matrixes exhibit excellent mechanical and thermal properties, low shrinkage upon curing, very good chemical and corrosion resistance properties and good process ability under variable working conditions. However, epoxy or epoxy-based materials have very poor impact resistance properties. To improve the impact resistance, several solutions have so far been proposed [2]. The insertion of elastomeric particles is one of the most common ones that softens rigid thermoset matrices [3]. This method involves dissolving chemically modified elastomeric particles in the thermosetting resin. This method has the disadvantage of reducing the effective stiffness of the final product. In addition, the introduction of thermoplastic particles in epoxy resins can improve their toughness [4,5]. A new innovative method to improve epoxy resins' impact resistance

\footnotetext{
* Corresponding author. Tel.: +33 0688310915.

E-mail address: matadi@enim.fr (R. Matadi Boumbimba).
}

was recently reported in the literature. It consists of using an epoxy nanocomposite as a matrix in the final composites [6]. Carbon nanotubes (CNTs), layered clay [7], rigid nanoparticles or combinations of these particles were frequently used in epoxy nanocomposite-based fibre composite materials [8]. Because of their small size, rigid nanofillers have proven to be effective in improving both the toughness and the stiffness of the final composite [7,9,10]. In particular, well-dispersed silica nanoparticles have been adopted to strengthen epoxy resins [11]. Ferreira et al. [12] studied the fatigue strength of a Kevlar/epoxy laminate composite and reported positive effects of using epoxy organoclay as the matrix in epoxy composites. It was found that 12 wt.\%-filled composites had significantly improved tensile fatigue strength. However, the fatigue strength of filled composites was lower in the three point bending test. Gojny et al. [13] have investigated the tensile properties of glass fibre-reinforced carbon nanotube/ epoxy matrixes. They showed that the tensile properties of laminates were not affected by the presence of CNTs and the inter-laminar shear strength and fracture toughness were improved.

Many papers report studies of low velocity impact behaviour of fibre/nanoparticle-epoxy resins. Hosur et al. [14] showed that the addition of nanoclay into the system reduced the impact damage, although the impact response in terms of peak load remained mostly unaltered. Similar improvements in inter-laminar fracture toughness have been reported. Studies performed by Ávila et al. 
[15] showed that the introduction of nanoclays into glass fibre/ epoxy composites increased the delaminated areas after low velocity impact tests. This phenomenon can be attributed to interlaminar shear forces created by the intercalated nano-structures. Nanoclays also increased the energy absorption capacity of glass fibre composites by approximately $48 \%$ when loaded with low energy ( $20 \mathrm{~J})$.

Although such systems exhibit improved properties, their effectiveness greatly depends on the successful dispersion of nanofillers in polymer resins. The three main techniques used to prepare nanocomposites are melt intercalation, in situ polymerisation and solvent intercalation [16]. To obtain exfoliated systems with excellent physical properties, nanofiller modification and solvent elimination are commonly applied. However, these treatments can be very costly. To overcome the need for these modifications of epoxy matrix nanocomposites, an innovative solution is to use acrylic tri-block-copolymers (developed and marketed by Arkema, under the trade name Nanostrength), which can easily be solubilised in epoxy resins. Acrylic tri-block-copolymers have the ability to self-assemble to form nanostructures (e.g., micelles, vesicles) through selective chemical interactions with the epoxy matrix [17]. Although epoxy resin filled with acrylic tri-block-copolymers present a significant enhancement in properties [18], their use as a matrix in laminate composite materials has received less attention. To the best of our knowledge, only two studies have been reported in the literature. Bashar et al. [19] showed that the fracture behaviour of a basalt fibre/epoxy resin can be significantly improved by the presence of nanoparticles. They have demonstrated that micelle structures were formed by acrylic tri-block-copolymers in epoxy resins, and these led to cavitation during plane-strain fracture, followed by subsequent matrix deformation. Such effects were attributed to excellent toughness improvements of the bulk epoxy. In the work by Denneulin et al. [20], whose focus is on the low impact behaviour of Aramids fibres/epoxy-acrylic tri-block composite laminates, the authors demonstrated that the impact resistance of the composites was improved in the presence of acrylate tri-block (Nanostrength).

In this study, acrylic tri-block copolymers (Nanostrength)-modified epoxy nanocomposite systems were prepared and used as a matrix in woven glass fabric laminate composites. Glass fabrics were impregnated with neat epoxy resin and epoxy-based Nanostrength for the fabrication of composite laminates. Composite morphology was investigated by means of atomic force microscopy (AFM) and scanning electron microscopy (SEM). Impact resistance as well as thermomechanical properties of the composites, with and without Nanostrength, were also investigated.

\section{Experimental characterisation}

\subsection{Materials}

The polymer resin used in this work is a thermoset epoxy precursor DGEBA (EPOLAM2020), with low viscosity, supplied by Axson Technologies. The EPOLAM 2020 hardener, also supplied by Axson Technologies, is used in a ratio of $0.345(\mathrm{w} / \mathrm{w})$ (corresponding to $34.5 \mathrm{~g}$ of hardener for $100 \mathrm{~g}$ of resin). The fibre fabric used is a plain bi-directional woven fabric of glass fibres (supplied by Composites Distribution) with a thickness of $0.15 \mathrm{~mm}$ and surface density of $202 \mathrm{~g} / \mathrm{m}^{2}$. The acrylic tri-block copolymers, M52N, named Nanostrength and supplied by ARKEMA (GRL, France), are symmetric MAM copolymers. MAM copolymers have a poly(butyl acrylate) centre block and two poly (methyl methacrylate) side blocks (Fig. 1a), designed for epoxy formulations such as DGEBA, whatever hardener ("Thermoset materials with improved impact resistance", WO2006/077153). The PMMA blocks give compatibility to epoxy resin, while the PBuA blocks provide an immiscible soft rubber phase for toughening. Compared to conventional reactive rubber modifier such as carboxy-terminated butadiene acrylonitrile (CTBN), or rubber core or thermoplastic spheres, Nanostrength can easily be dissolved in epoxy resin, with application of heat and a low amount of shear. When dissolved in epoxy, Nanostrength self-assemble into nanostructures. The PMMA block will associate with epoxy resin forming an effective shell surrounding an immiscible PBuA core. The final epoxy based Nanostrength structuration depends on the chemical nature of crosslinker and the chemical composition of the blocks copolymer. In the final material Nanostrength are present either in form of worm-like micelles or in the form of the vesicles (Fig. 1b).

\subsection{Processing}

Prior to preparation of the composites, the Nanostrength powder is dissolved in the epoxy resin. The powder M52N is initially mixed with the EPOLAM2020 epoxy resin in an oven, at a mixing temperature of $130{ }^{\circ} \mathrm{C}$ and a mixing rate of $290 \mathrm{rpm}$, for $2 \mathrm{~h}$. The chosen temperature allows the block copolymers to dissolve into the epoxy resin. Two Nanostrength weight concentrations (5 wt.\% and $10 \mathrm{wt} . \%$ ) were used for preparation of the composites. Because the addition of Nanostrength leads to an increase in resin viscosity, a low viscosity di-functional aliphatic reactive diluent (RD107) based on hexanediol (from Epotec) was added to limit the increase of viscosity. Furthermore, the processing pressure and the addition of RD107 were also investigated. Fig. 2 shows the three different resins used for the preparation of the three laminated composites that were investigated in this study.

A typical composite panel's preparation protocol consisted of first putting the glass fabric in an oven for $20 \mathrm{~min}$ at $80^{\circ} \mathrm{C}$. Then, a blend of epoxy precursor and hardener was poured on both faces of the woven glass fabric. Then, the same operation was repeated for the second woven fabric before the superimposition of the two woven fabrics. The glass fabric impregnation was done by hand. Our composite panel was composed of five woven glass fabrics. Special care was taken to ensure that the five impregnated layers of glass fabrics were disposed with a $0^{\circ}$ relative orientation with respective to each other. After the impregnation of the woven glass fabrics, a hot press was used to supply accurate temperature and pressure to cure the composites. The first stage was compression of the impregnated layers, under 10 or 20 bars, at a temperature of $90^{\circ} \mathrm{C}$. The second stage was post-curing in an oven at $80^{\circ} \mathrm{C}$ for $2 \mathrm{~h}$. The same procedure was followed for glass fibre/epoxy modified Nanostrength laminate composites.

Fibre weight fractions of these composite materials were determined by Thermo-gravimetric Analysis (TGA). TGA was performed using a thermal analysis NETZSCH STA 409 PC-Luxx Instrument, under nitrogen, at a heating rate of $40{ }^{\circ} \mathrm{C} / \mathrm{min}$ and a temperature range from $30^{\circ} \mathrm{C}$ to $900{ }^{\circ} \mathrm{C}$. For each composite system, four specimens were cut with a cookie cutter and subjected to TGA. The TGA curves (Fig. 3) reveal that both composites degrade in two steps. However, given that our study does not address the degradation of two composites, we not give more details on the process of degradation of these composites. The glass fibre weight fraction of both composites is then measured by the means of weight loss. According to the TGA curves (Fig. 3), this glass fibre weight fraction is about $70 \%$. The material sample names and the processing conditions are listed in Table 1.

\subsection{Measurement and characterisation}

Atomic force microscopy (AFM) was performed by using a Dimension 3100 (VEECO) in tapping mode. To determine the Nanostrength shapes and spatial distribution in the laminate composite, AFM observations were performed on ion-polished specimens. 
(a)

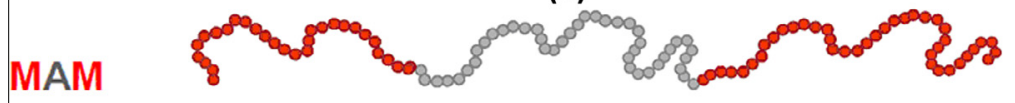

Poly[(Methyl)methacrylate] -b- poly(Butyl Acrylate) -b- poly[(Methyl)methacrylate]

(b)

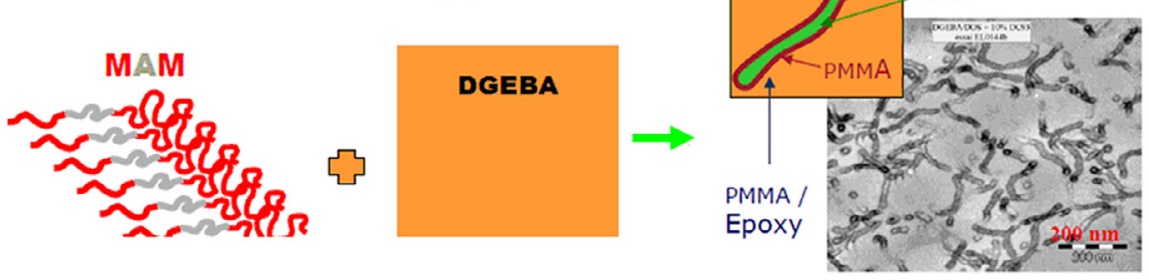

Fig. 1. (a) Schematic representation of Arkema's MAM Nanostrength ${ }^{\circledR}$ block copolymers, (b) TEM images of self assembled nanostructures in epoxy resin.
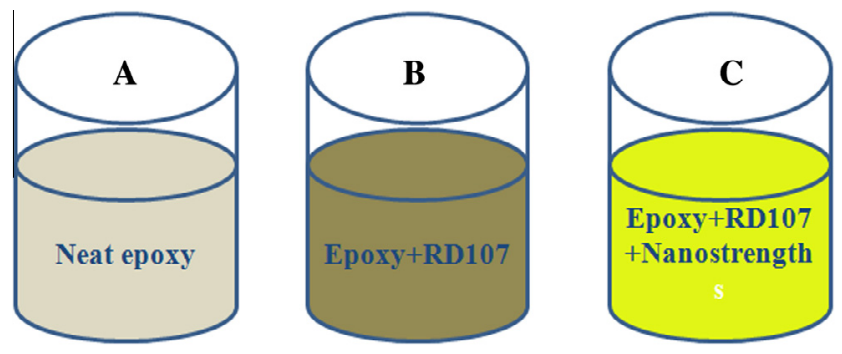

Fig. 2. Schematic representation of the different resin mixtures.

Dynamic modulus and relaxation temperatures of the laminate composites with or without Nanostrength were measured by a Netzch DMA 242C dynamic mechanical analyser (DMA). The thermograms of EPO_FV, EPONS_FV and EPO_RD107_FV composites were obtained in torsional mode, at a vibration frequency of $1 \mathrm{~Hz}$, constant static strength of $0.5 \mathrm{~N}$, a temperature range from $30{ }^{\circ} \mathrm{C}$ to $150{ }^{\circ} \mathrm{C}$ and a heating rate of $5^{\circ} \mathrm{C} / \mathrm{min}$ in air atmosphere. The specimens used for DMA analyses had dimensions of $25 * 12 * 0.5 \mathrm{~mm}^{3}$.

Impact tests on composite specimens were performed with a drop weight tower. This device consists of two columns attached to a metallic gantry (Fig. 4(a)). The two columns guide the falling carriage, on which different impactor geometries can be fixed. A winch with an electromagnet is used to lift the projectile (from $1 \mathrm{~kg}$ to $5 \mathrm{~kg}$ ) to the desired impact height (up to $2 \mathrm{~m}$ ), which is a function of the velocity required. During the test, the projectile is released by an electromagnet, falls freely and then strikes the structure. An anti-bouncing device is used to avoid a second impact, which could further damage the structure and prevent post-mortem analysis of the damage and residual strain. By placing a piezoelectric force sensor (Bruel \& Kjaer 8230 C-003 force transducer, force range of $5 \mathrm{kN}$ ) under the projectile, the force response of the structure during impact can be determined. During the test, the specimen was held with clamped edges, in a circular support with 70-mm diameter. The plates were clamped by four screws with a torque of $20 \mathrm{Nm}$. The steel impactor used for the study was a hemispherical impactor with $16-\mathrm{mm}$ diameter. The impact tests were conducted at an impact energy of $8.8 \mathrm{~J}$, which corresponds to a drop height of $0.5 \mathrm{~m}$. The total mass (of carriage plus impactor) is $1.77 \mathrm{~kg}$. As a supplementary tool, a Photron FASTCAMAPX RS high-speed video camera was used, to observe the back face of the composite structure during the impact (a mirror was placed at $45^{\circ}$ beneath the sample to reflect the image of the deformed sample) (Fig. 4(a)) to better understand the test results. Displacement was measured via a second high-speed video camera (Photron SA3), which tracked a grid stuck on the impactor. For each type of composite, the tests were repeated six times to ensure test repeatability.
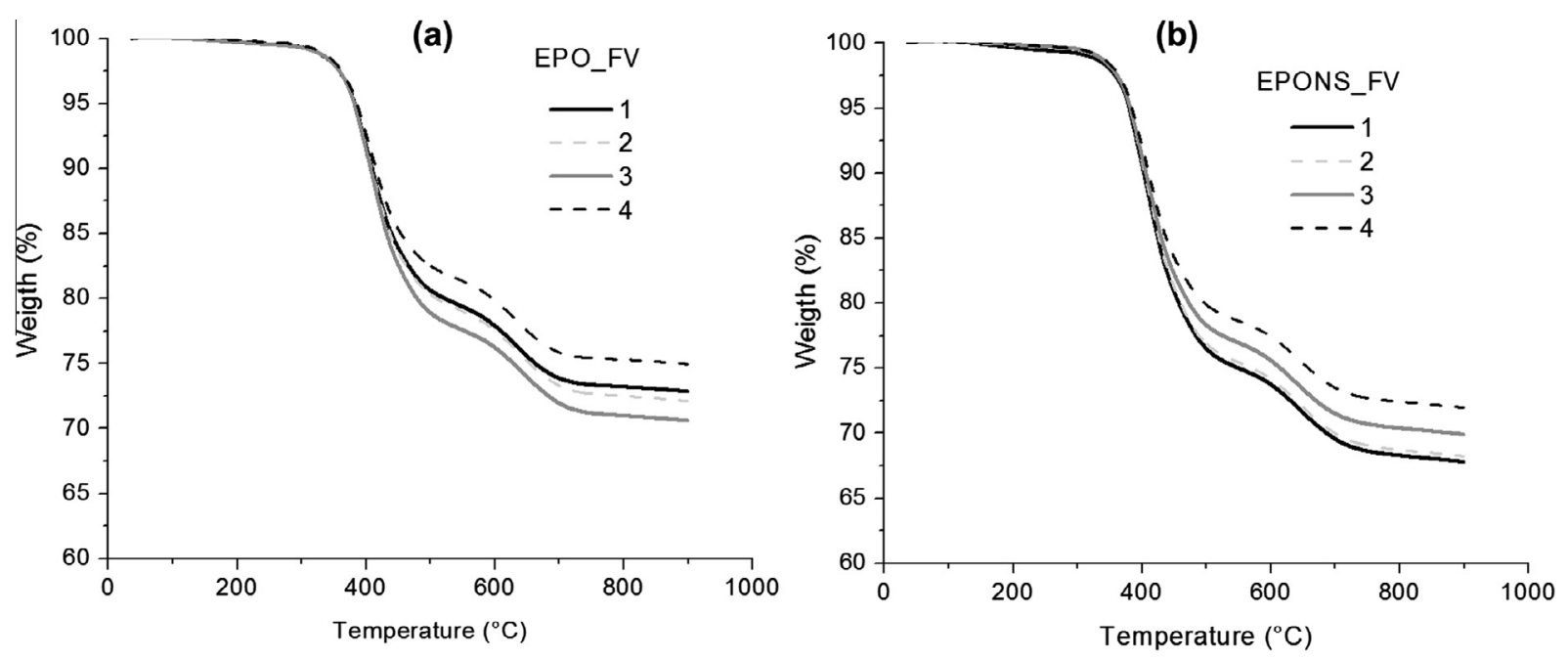

Fig. 3. TGA thermograms of (a) EPO_FV and (b) EPONS_FV. 
Table 1

Sample names and processing conditions.

\begin{tabular}{|c|c|c|c|c|}
\hline Sample & Curing pressure (bar) & Curing temperature $\left({ }^{\circ} \mathrm{C}\right)$ & Post-curing temperature $\left({ }^{\circ} \mathrm{C}\right)$ & Nomenclature \\
\hline Glass fibre/epoxy & 10 & 90 & 80 & EPO_FV_10 \\
\hline Glass fibre/epoxy & 20 & 90 & 80 & EPO_FV_20 \\
\hline Glass fibre/epoxy + Nanostrength & 10 & 90 & 80 & EPONS_FV_10 \\
\hline Glass fibre/epoxy + Nanostrength & 20 & 90 & 80 & EPONS_FV_20 \\
\hline Glass fibre/epoxy + RD107 & 10 & 90 & 80 & EPO_RD107_FV_10 \\
\hline Glass fibre/epoxy + RD107 & 20 & 90 & 80 & EPO_RD107_FV_20 \\
\hline
\end{tabular}

(a)

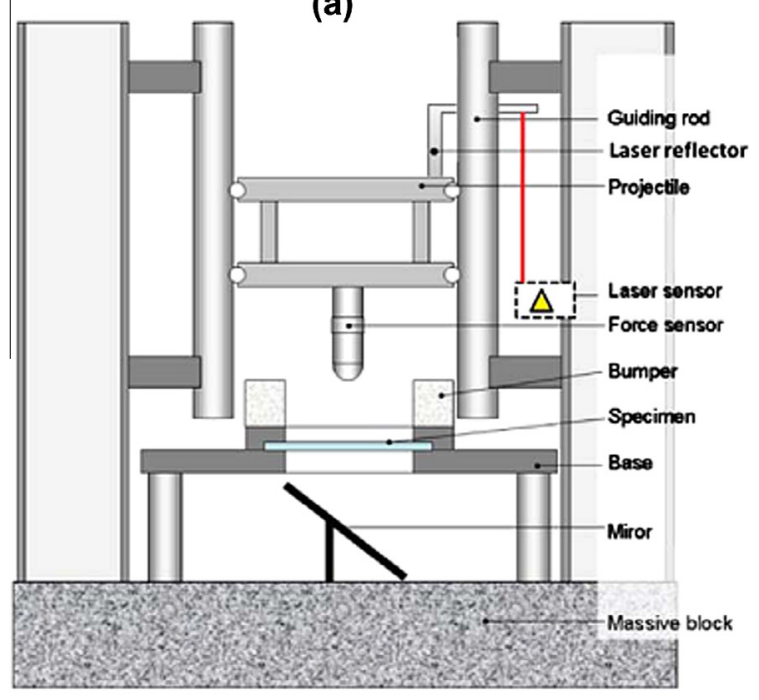

(b)

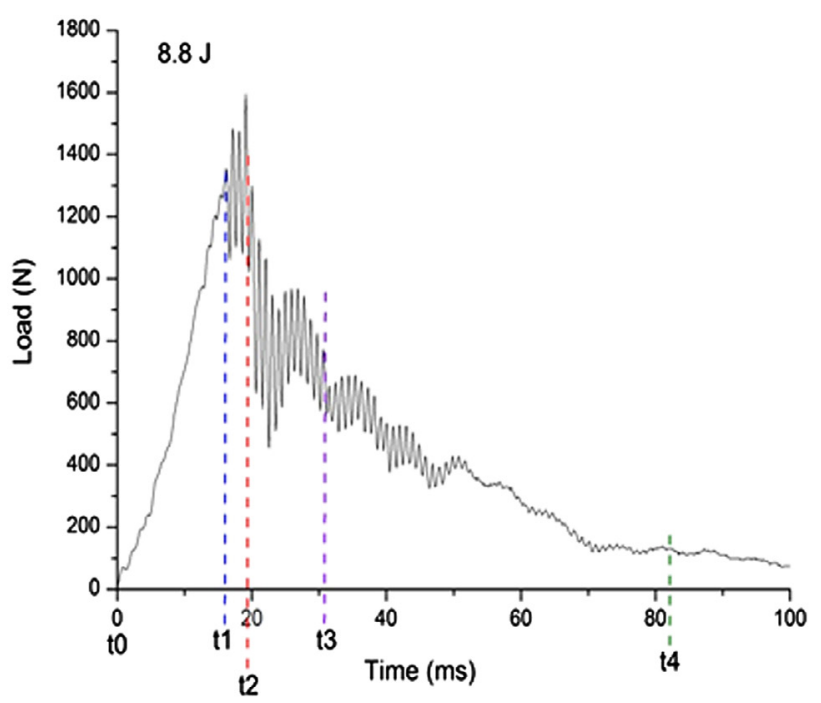

Fig. 4. (a) Schematic representation of drop tower; (b) typical load vs. time response for EPONS_FV_20.

Typical force versus time curves (Fig. 4 (b)), obtained after impact testing, showed indications of four phases. The first phase (between [t0, t1] ) corresponds to elastic bending of the composite plate. Between $[t 1, t 2]$, the increase in load is less pronounced and corresponds to a first drop of the composite stiffness because of damage initiation. The damage consists mainly of matrix cracking, which can be detected in the plot by the presence of small oscillations. The maximum force is reached at $\mathrm{t} 2$. Within the interval [ $\mathrm{t} 2$, $\mathrm{t} 3$ ], the significant drop of load is due to damage propagation in the composite plate structure. The failure of fibres occurs at this stage. The last phase $[\mathrm{t} 3, \mathrm{t} 4]$ corresponds to the residual strength of the composite plate and to dry friction during impactor penetration. In the following, the load at which the damage initiation takes place is denoted by $F_{\text {init }}$, and the maximum load is denoted by $F_{\text {max. }}$ The impact resistances of the composites were characterised in terms of the changes in $\mathrm{F}_{\text {init }}$ and $\mathrm{F}_{\mathrm{max}}$. Scanning electron microscopy (SEM) (JSM 840) was used to investigate the composite plates after impact tests.

\section{Results and discussion}

\subsection{Dispersion of Nanostrength in the composite}

Topographic and phase AFM images were obtained from EPO_FV_10 and EPONS_FV_10 surfaces. In the case of the EPO_FV_10 composite, the fibres and the matrix are clearly distinguished (Fig. 5(a)). The relief is mainly due to the effect of the surface preparation, which is because of the sputtering rate being different for the fibres and the matrix. The direction of the ion sputtering can also be identified by the shape of the surface corrugations. The AFM successfully confirmed the presence of acrylic tri-blocks copolymers in the matrix of the EPONS_FV_10 composite (Fig. 5(b)). In both topographic and phase images, the Nanostrength is clearly identified. Nanostrength is present in the form of elongated micelles with an average dimension of around hundred nanometres. The spatial distribution of the micelles, which is clearly not affected by the ionic sputtering process, is very good, without evidence of clustering. These observations show that the matrix nanostructuration is as effective after woven fabric impregnation as for the matrix in bulk systems. This good dispersion of Nanostrength in EPONS_FV_10 composite can be attributed to the ability of powdered Nanostrength to dissolve easily in the epoxy resin and to the role of the reactive diluent. Having worked on neat epoxy filled with Nanostrength, Arkema researchers showed that the best toughness improvement was obtained when the Nanostrength was present as elongated micelles [21].

\subsection{Effect of processing pressure}

Fig. 6 presents the variation of storage modulus, loss modulus and damping factor as a function of temperature, for EPO_FV and EPONS_FV. One can observe that there is no change in the viscoelastic properties of the two composites with the increase of the processing pressure. Additionally, there is no effect of processing pressure on the glass transition temperatures $(\mathrm{Tg})$ of the composites, either. In fact, for the EPO_FV system, the glass transition temperature equals approximately $98^{\circ} \mathrm{C}$ for both processing pressures. The same behaviour is observed for the EPONS_FV composite, for which the $\mathrm{Tg}$ is evaluated to be $87^{\circ} \mathrm{C}$ for the two processing pressures. These results are confirmed by those obtained from the 


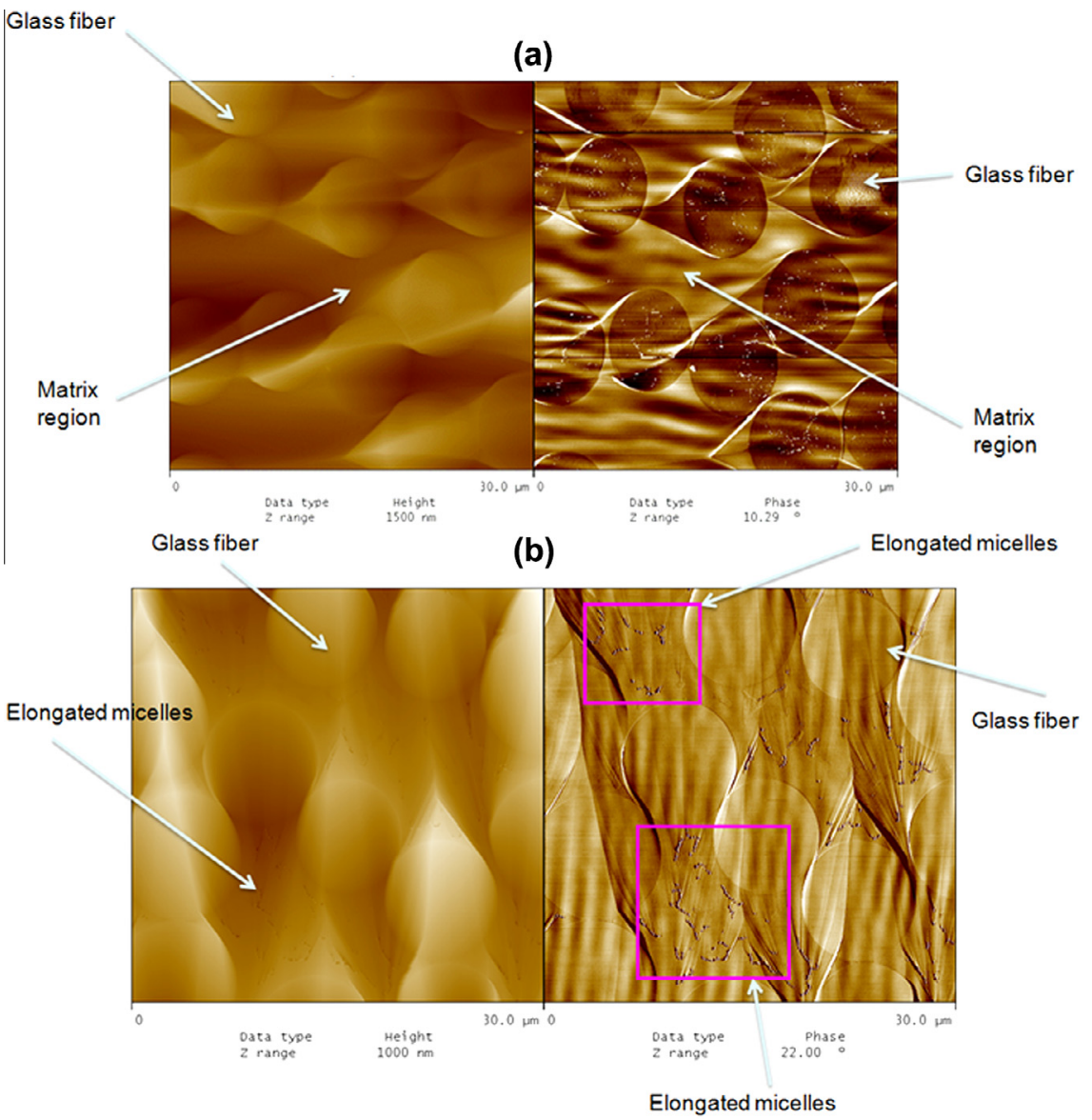

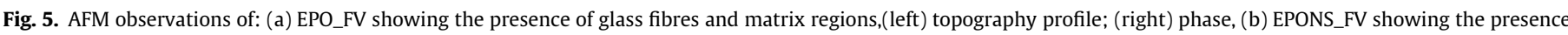
of Nanostrength in form of elongated micelles, (left) topography profile; (right) phase.

(a)

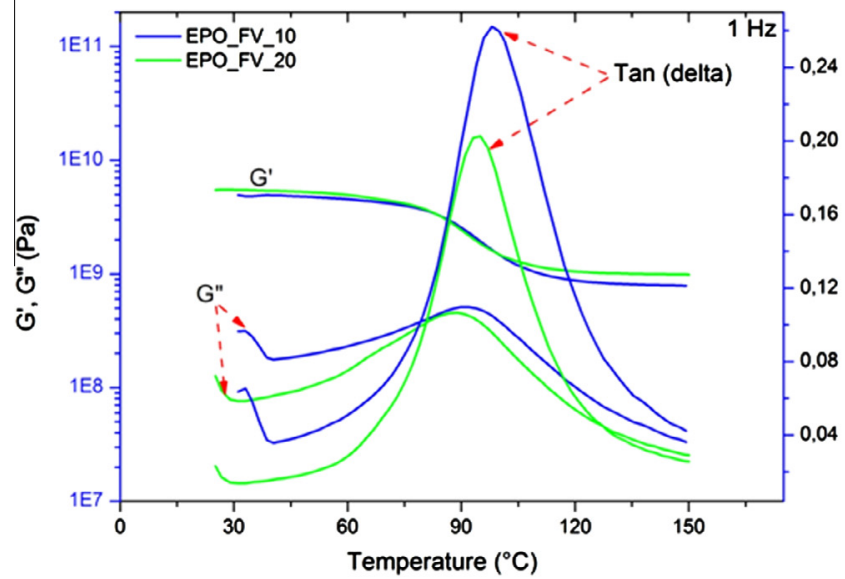

(b)

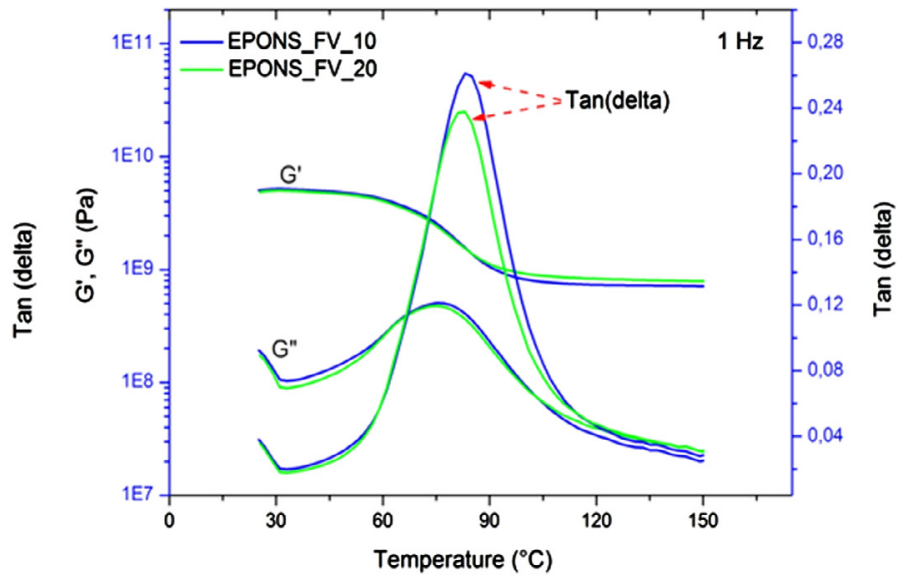

Fig. 6. DMA data, storage modulus $\left(\mathrm{G}^{\prime}\right)$, loss modulus $\left(\mathrm{G}^{\prime \prime}\right)$ and damping factor (tan (delta)) versus temperature. (a) EPO_FV, (b) EPONS_FV.

impact resistance tests. As shown in Fig. 7, the force/displacement curves for EPO_FV and EPONS_FV, fitted for the two processing pressures, overlap quite well and do so for all of the curve regions. Thus, it appears that pressures above 10 bars were not required for this fabric geometry. It seems that increasing the processing pressure acts only to remove a few intra-bubbles. Due to this, we focused only on composites prepared at a processing pressure of 10 bars.

\subsection{Viscoelastic properties}

In this section, the effect of reactive diluent and Nanostrength addition on viscoelastic properties, is investigated and discussed. The storage modulus $\left(\mathrm{G}^{\prime}\right)$, determined at a frequency of $1 \mathrm{~Hz}$, is plotted as a function of temperature for EPO_FV_10, EPO_RD107_FV_10 and EPONS_FV_10 (Fig. 8(a)). According to these results, the addition of both Nanostrength and reactive 

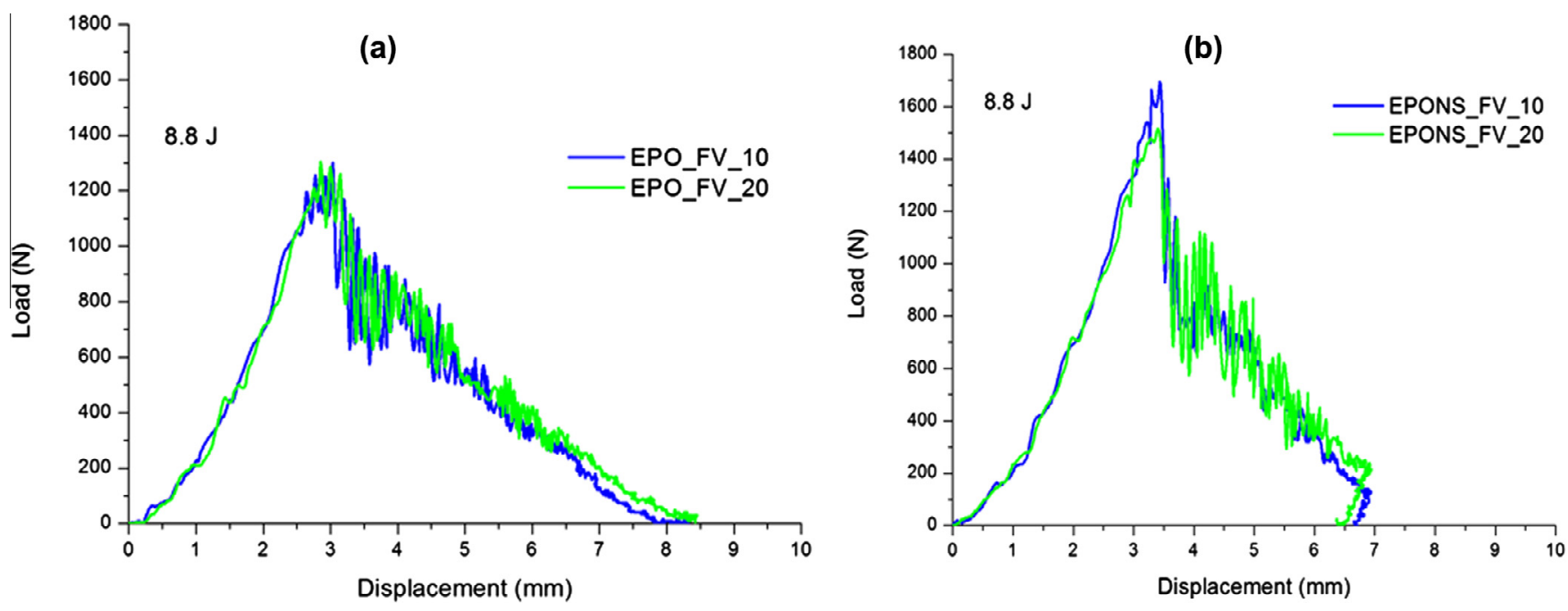

Fig. 7. Load vs. displacement curves, obtained at $8.8 \mathrm{~J}$, (a) EPO_FV, (b) EPONS_FV.

diluent leads to a decrease of the storage modulus. In the glassy state region, this effect is very significant for EPONS_FV_10. As reported in Table 2(a), the storage modulus of EPONS_FV_10, in the glassy region decreases by $33 \%$ at $40{ }^{\circ} \mathrm{C}$, when compared to that of EPO_FV_10. In contrast the storage modulus of EPO_RD107_FV_10 increases slightly, by $12 \%$, at $40^{\circ} \mathrm{C}$. This decrease is also observed in the rubbery state for both EPONS_FV_10 and EPO_RD107_FV_10 (see Table 2(a)). The drop in $\mathrm{G}^{\prime}$ with the addition of Nanostrength is probably due to the presence of nanostructured rubber phase (polybutyl acrylate), which acts as a soft phase in the composite. The other factor that could explain this reduction is the fact that the addition of both reactive diluent and Nanostrength could change the cross-linking density of the epoxy.

The loss modulus $\left(\mathrm{G}^{\prime \prime}\right)$ curves as a function of temperature are presented in Fig. 8(a). As for $\mathrm{G}^{\prime}$, the loss modulus decreases with the addition of reactive diluent and Nanostrength. The variation of damping factor ( $\tan ($ delta)) with temperature for laminates is shown in Fig. 8(b), where a single relaxation is observed. The glass transition temperature ( $\mathrm{Tg}$ ), corresponding to the peaks of the damping factor curves (Fig. 8(b)), decreases with the addition of
Table 2

(a) DMA values taken at different temperatures; (b) impact test results.

\begin{tabular}{|c|c|c|c|c|c|c|c|}
\hline & \multicolumn{3}{|c|}{$\mathrm{G}^{\prime}(\mathrm{MPa})$} & \multicolumn{3}{|c|}{$\mathrm{G}^{\prime \prime}(\mathrm{MPa})$} & \multirow{2}{*}{$\begin{array}{l}\mathrm{Tg} \\
\left({ }^{\circ} \mathrm{C}\right)\end{array}$} \\
\hline & $40^{\circ} \mathrm{C}$ & $90^{\circ} \mathrm{C}$ & $130^{\circ} \mathrm{C}$ & $40^{\circ} \mathrm{C}$ & $90^{\circ} \mathrm{C}$ & $130^{\circ} \mathrm{C}$ & \\
\hline \multicolumn{8}{|l|}{ (a) } \\
\hline EPO_FV_10 & 4900 & 2310 & 820 & 170 & 510 & 58 & 98 \\
\hline EPO_RD107_FV_10 & 5600 & 1660 & 724 & 234 & 244 & 29 & 85 \\
\hline \multirow[t]{2}{*}{ EPONS_FV_10 } & 3250 & 619 & 401 & 123 & 176 & 18.6 & 87 \\
\hline & $\begin{array}{l}F \text { init } \\
(\mathrm{N})\end{array}$ & $\begin{array}{l}\mathrm{F} \max \\
(\mathrm{N})\end{array}$ & \multicolumn{3}{|c|}{$\begin{array}{l}\text { Displacement } \\
\max (\mathrm{mm})\end{array}$} & \multicolumn{2}{|c|}{$\begin{array}{l}\text { Dissipated } \\
\text { energy }(\mathrm{J})\end{array}$} \\
\hline \multicolumn{8}{|l|}{ (b) } \\
\hline EPO_FV_10 & 1195 & 1250 & 2.9 & & & 3.3 & \\
\hline EPO_RD107_FV_10 & 1204 & 1248 & 3.2 & & & 3.4 & \\
\hline EPONS_FV_10 5\% & 1210 & 1500 & 3.4 & & & 3.7 & \\
\hline EPONS_FV_10 10\% & 1530 & 1665 & 3.3 & & & 3.9 & \\
\hline
\end{tabular}

reactive diluent and Nanostrength from approximately $98^{\circ} \mathrm{C}$ for EPO_FV_10 to $87^{\circ} \mathrm{C}$ and $85^{\circ} \mathrm{C}$ for EPONS_FV_10 and EPO_RD107_FV_10, respectively. One can see that there is no change in the glass transition temperature between EPO_RD107_FV_10 and EPONS_FV_10. Because there is no great (a)

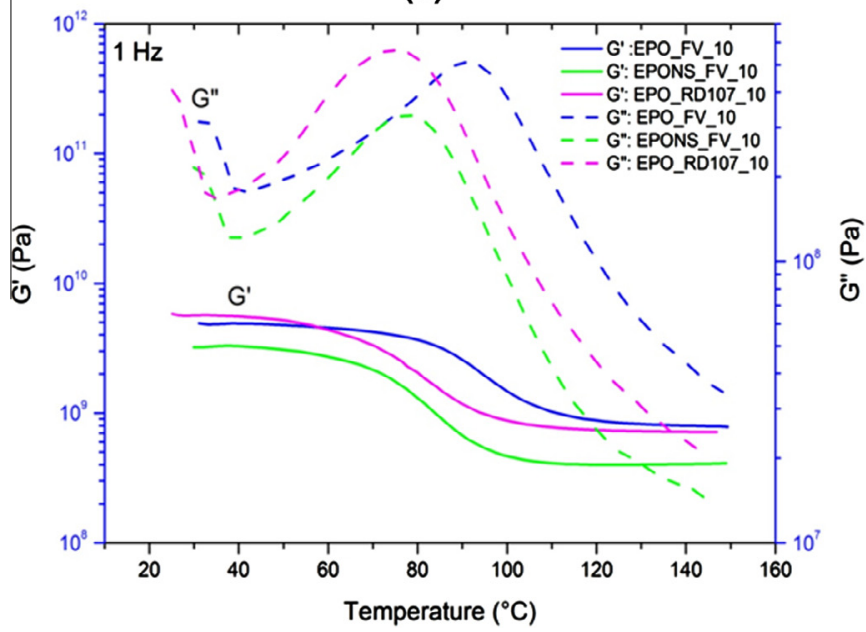

(b)

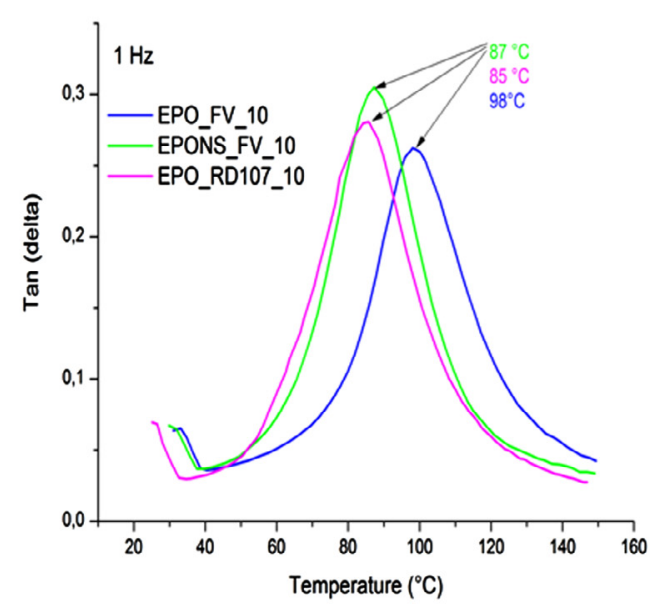

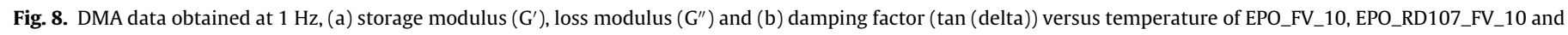
EPONS_FV_10. 
difference between the Tgs of EPO_RD107_FV_10 and EPONS_FV_10, the presence of the reactive diluent in EPONS_FV_10 seems to be the main cause for the decrease of $\mathrm{Tg}$. The reactive diluent acts as a plasticising agent on the epoxy network. Different peak heights indicate that the damping properties of the three laminate composites are different. Generally, the increase of damping factor peak height indicates either good mobility of molecular chains or poor interfacial adhesion between the matrix and the fibres. In our case, this change is more related to good mobility of the polymer chains, induced by the addition of a soft nanostructured rubber phase into the epoxy matrix. Thus, according to results depicted in Fig. 8(b), the restriction of polymer chain mobility is more effective in EPO_FV_10 than in EPONS_FV_10. This observation leads to the conclusion that the combination of reactive diluent and Nanostrength addition improves the mobility of the epoxy matrix chains. Based on dynamical mechanical analysis (DMA), Yang et al. [22] reported an increase in Tg and a decrease in storage modulus, in the presence of Poly(3-caprolactone)block-poly(butadiene-co-acrylonitrile)-blockpoly(3-caprolactone) tri-block copolymer (PCL-b-PBN-b-PCL). The authors believe that the increase of $\mathrm{Tg}$ is due to the reduction in plasticisation of the modified epoxy, induced by reduced interpenetration of PCL chains into the nanostructured epoxy. In our system, the decrease of Tg is only linked to the use of reactive diluent, which causes some changes in the cross-linking density of the epoxy matrix.

\section{4. impact resistance}

Fig. 9(a) shows load versus displacement curves for the laminate composites containing 0,5 and $10 \mathrm{wt} . \%$ of Nanostrength. It can be seen that the slope of the load displacement curves, which is designated as the contact stiffness, remains the same. The peak $\mathrm{F}_{\text {init }}$, at which point damage initiates, increases from $1195 \mathrm{~N}$ for EPO_FV_10, to 1210 and $1530 \mathrm{~N}$ for EPONS_FV_10 (5 wt.\%) and EPONS_FV_10 (10 wt.\%), respectively. In the same way, the maximum load peak $\left(F_{\max }\right)$, goes from $1250 \mathrm{~N}$ for EPO_FV_10 to 1500 and $1665 \mathrm{~N}$ for EPONS_FV_10 (5 wt.\%) and EPONS_FV_10 (10 wt.\%), respectively, corresponding to an improvement of $20 \%$ and 33\%, respectively. Load versus displacement diagrams showing the effect of both reactive diluent and Nanostrength addition are presented in Fig. 9(b). As shown in Fig. 9(b), the use of reactive diluent (EPO_RD107_FV_10) had no effect on the impact resistance properties of the composites. No change was observed in curve slopes, in $F_{\text {init }}$ or in the maximum Load $\left(F_{\max }\right)$. However, a significant improvement was obtained in the impact resistance with the addition of Nanostrength. This enhancement consists in an improvement of $25 \%$ in $\mathrm{F}_{\text {init }}, 33 \%$ in $\mathrm{F}_{\max }$ and $19 \%$ in the displacement corresponding to the maximum load. In fact, both $\mathrm{F}_{\text {init }}$ and $\mathrm{F}_{\max }$ increase from $1195 \mathrm{~N}$ and $1250 \mathrm{~N}$ to $1530 \mathrm{~N}$ and $1665 \mathrm{~N}$, respectively, with the addition of $10 \mathrm{wt} . \%$ of Nanostrength. It can be seen that there is no significant change in the elastic properties with Nanostrength addition. The dissipative energy, corresponding to the area of the force displacement curve between [t $0, t 3]$, also increases with the addition of Nanostrength. The impact results, consisting of $\mathrm{F}_{\text {init }}, \mathrm{F}_{\max }$, the displacement at maximum load and dissipated energy for all of the laminate composites are listed in Table 2(b). Some reports discuss the possible ways to improve the toughness of the fibre-epoxy laminate composites. One such method consists of using compatibilising agents on fibre fabrics, to improve fibre/epoxy interfacial adhesion [23]. An alternative approach is the selective toughening of interface regions between plies [24]. This method consists of applying a thin adhesive layer at the interface between plies, to inhibit delamination. This approach is similar to the dispersion of thermoplastic powder onto one surface of prepreg. Finally, the third method consists of toughening the epoxy matrix [18]. Because this solution is the one we choose in our work, the toughening mechanisms of our laminate composites are mainly due to epoxy matrix toughening mechanisms. The improvement in toughness of the epoxy through formation of a nanostructured phase can be related to the following factors: the elastomeric phase $(\mathrm{PBu})$ is homogenously dispersed in the epoxy matrix at a nanometre scale, which can greatly enhance interaction between the epoxy matrix and the Nanostrength. Because the Nanostrength is reactive, chemical bonds can be created between the epoxy matrix and the Nanostrength. In addition, the improvement of impact resistance in this nanostructured system can be related to the decrease in crosslinking density of the thermoset epoxy matrix. Ahead of the crack front, Nanostrength seems to be able to interact within the plastic zone to suppress the coalescence of micro-cracks and voids. The Nanostrength may act to shield the matrix from damage by bridging cracks. Finally, the toughening of the epoxy-modified Nanostrength composite is also caused by the Nanostrength rubber phase nanocavitation, which can induce matrix shear banding [25]. (a)

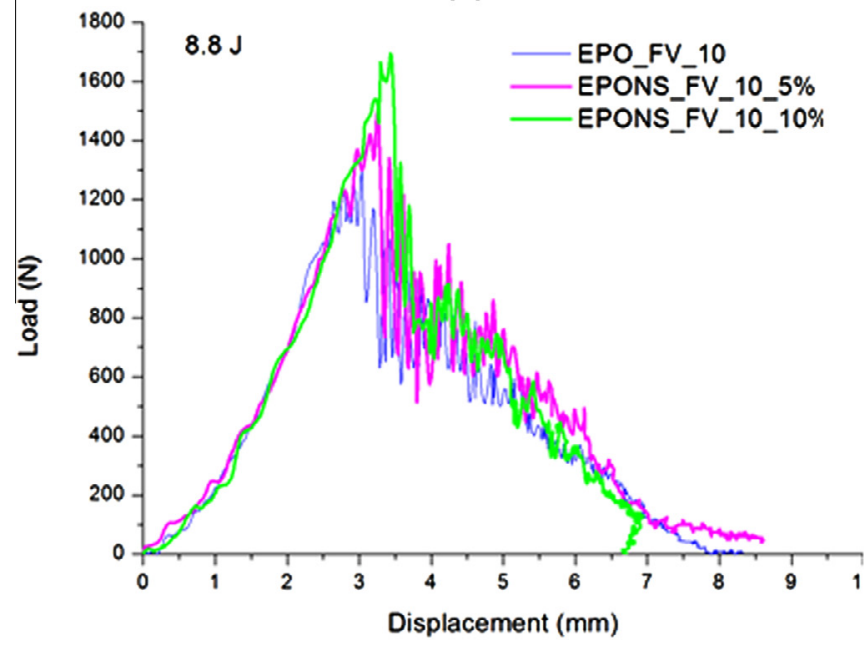

(b)

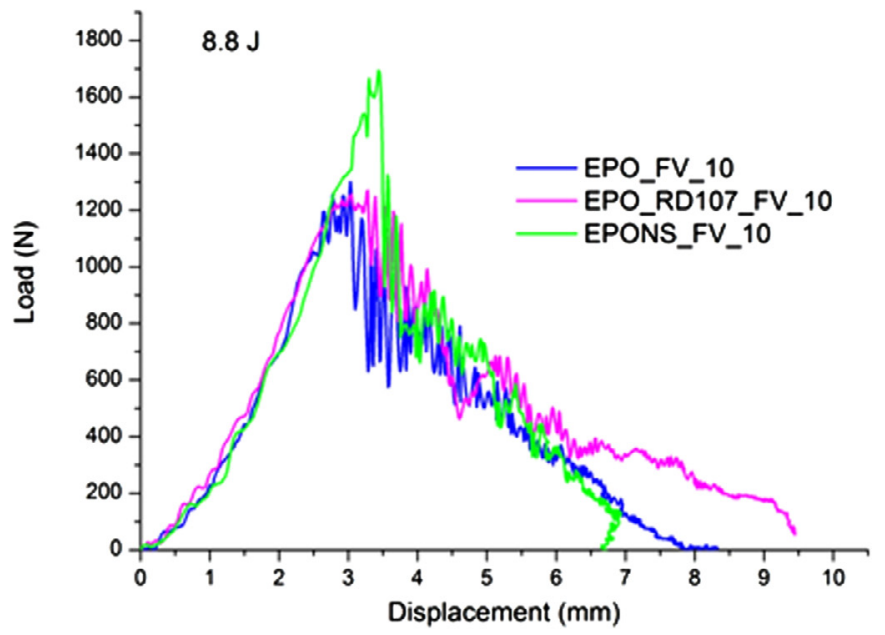

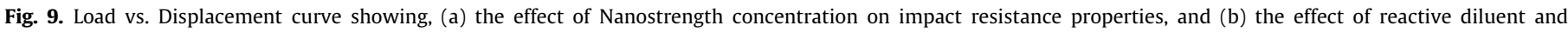
Nanostrength addition on impact resistance properties. 


\section{(A): EPO_FV_10}

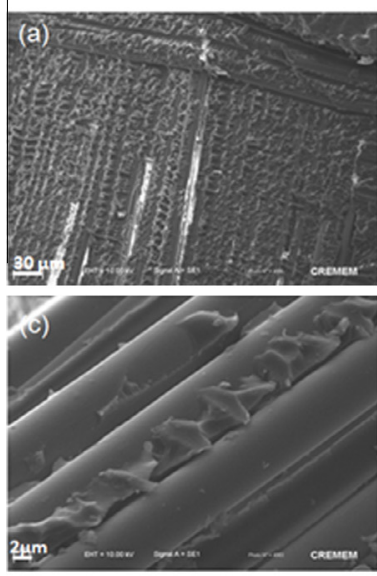

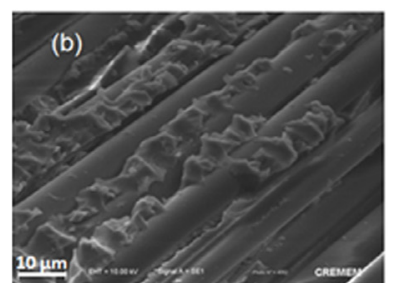

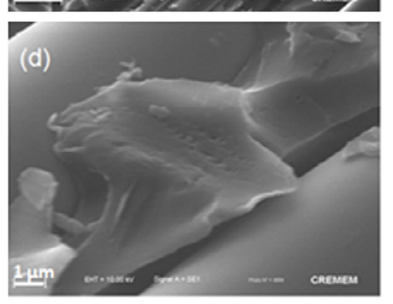

(B): EPONS_FV_10

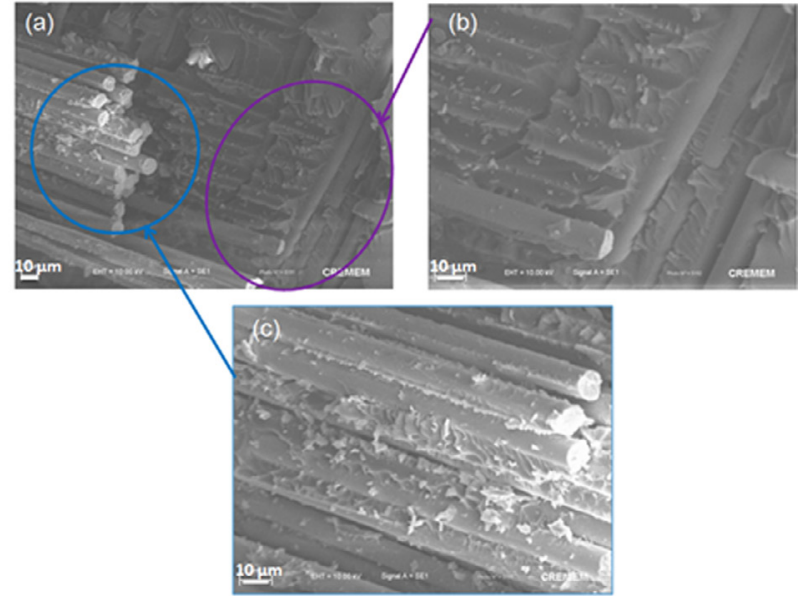

Fig. 10. SEM images of impacted plates at different magnifications; (A) EPO_FV_10, (B) EPONS_FV_10.

This last argument is well observed in polymer nanocomposite materials, suggested to high strain rate loading [26].

The enhancement of the impact resistance with the addition of acrylic tri-blocks copolymers consists of $25 \%$ improvement in $\mathrm{F}_{\text {init, }}$ $33 \%$ improvement in $\mathrm{F}_{\max }$ and $19 \%$ increase in the displacement corresponding to the maximum load. These results agree with the study published by Deunneulin et al. [20] on the effect of epoxy based acrylic tri-blocks copolymers aramid fibres composite. They observed that elastic limit detected by the first oscillation on the curve due to matrix cracking increase about $40 \%$ in terms of force and about $30 \%$ in terms of displacement. In other studies with organoclays or carbone nanotube-based epoxy as the matrix in fibre composites, the rule of nanoreiforcement in the toughening mechanism of fibre composites is evidenced. In the study of Reis et al. [27], it was observed that the addition of nanoclays promoted maximum loads around 16, 1\% higher than that occurred in Kevlar with pure epoxy resin. In another study by Taraghi et al. [28] on the low velocity response of Kevlar/epoxy laminated composites reinforced with carbon nanotubes, it is reported that the addition of 0.5 wt.\% carbon nanotube leads to around $21 \%$ increase in the maximum peak force. According to another experimental study on the low velocity impact resistance of thin, woven, carbon fabric composites incorporating multiwalled carbon nanotubes, addition of 1.5 wt.\% functionalized, multi-walled, carbon nanotube improves the penetration energy by $50 \%$ without degrading the peak force [29].

To understand the details of the toughening mechanisms, SEM was performed to examine the damaged region after impact. SEM observations in the damaged regions of EPO_FV_10 and EPONS_FV_10 are presented in Fig. 10. The fracture surface of EPO_FV_10 reveals a smooth matrix fracture surface, typical of a brittle fracture surface (Fig. 10(A)). Consistent with work performed by Arkema researchers [21], Nanostrength addition afforded a substantial number of crack deflection sites, visible through the rougher and ductile fracture zones of the EPONS_FV_10 composite. Major differences in primary fibrematrix adhesion were observed. The neat epoxy composite exhibited notable interstices (Fig. 10(B)) at the fibre-matrix interface, suggesting that the fibres had de-bonded during impact. In contrast, debonding does not occur in the case of the Nanostrength modified epoxy matrix. Furthermore, matrix coating the glass-fibre surface, indicates that addition of Nanostrength could lead to improved interfacial adhesion between glass fibre and epoxy matrix.

\section{Conclusions}

Glass fibre/epoxy-modified Nanostrength laminate composites were successfully prepared by compression moulding. Due to nanostructuration, Nanostrength provides superior toughening as compared to reactive rubber flexibilizers or core shell toughening agents, without sacrificing $\mathrm{Tg}$ or modulus. AFM observations showed that Nanostrength was well dispersed in the composite and was present in the form of worm-like micelles. Thermomechanical and impact tests revealed that there was no effect of processing pressure. The addition of Nanostrength led to a decrease of storage modulus, loss modulus and glass transition temperature. This decrease in viscoelastic properties is mainly due to the use of reactive diluent in the epoxy matrix. Impact resistance results, obtained through a drop tower device, revealed that the maximum load increased significantly with the addition of Nanostrength. This increase of maximum load is due to the presence of a well dispersed Nanostrength in the epoxy matrix. SEM observations of impact region revealed a smooth matrix fracture surface, typical of brittle fracture surface for EPO_FV_10. However, rougher and more ductile fracture zones were observed for EPONS_FV_10 composite. Overall, this study showed that Nanostrength easily can be used to enhance impact resistance properties of traditional epoxy laminate composites, with some significant applications in manufacturing helmets, boat hulls and aerospace structures. Compared to similar studies on hybrid lamellate composite systems, the proposed technique of this work brings about a better enhancement in the impact resistance. Adding Nanostrength has proven for Kevlar fibre and now glass fibre. This is a very interesting and advantageous way to easily increase the materials performance, especially with respect to low energy impacts.

\section{Acknowledgements}

The authors want to thank Mrs Peyrard Romain, Tony Maublanc and Dr Elodie Hablot, for their help and their availability.

\section{References}

[1] Hosur MV, Adbullah M, Jeelani S. Studies on the low-velocity impact response of woven hybrid composites. Compos Struct 2005;67:253-62.

[2] Atas C, Sayman O. An overall view on impact response of woven fabric composite plates. Compos Struct 2008;82:336-45. 
[3] Bagheri R, Pearson RA. Role of particle cavitation in rubber-toughened epoxies: 1. Microvoid toughening. Polymer 1996;37:4529-38.

[4] Hourston DJ, Lane JM. The toughening of epoxy resins with thermoplastics: 1. Trifunctional epoxy resin-polyetherimide blends. Polymer 1992;33:1379-83.

[5] Vieille B, Casado VM, Bouvet C. Influence of matrix toughness and ductility on the compression-after-impact behavior of woven-ply thermoplastic- and thermosetting-composites: a comparative study. Compos Struct 2014;110:207-18.

[6] Wang Z, Xu C, Zhao Y, Zhao D, Wang Z, Li H, et al. Fabrication and mechanical properties of exfoliated clay-CNTs/epoxy nanocomposites. Mater Sci Eng A 2008;490:481-7.

[7] Matadi R, Makradi A, Ahzi S, Sieffert JG, Etienne S, Rush D, et al. Preparation, structural characterization, and thermomechanical properties of poly(methyl methacrylate)/organoclay nanocomposites by melt intercalation. J Nanosci Nanotechnol 2009;9:2923-30.

[8] Goyat MS, Ray S, Ghosh PK. Innovative application of ultrasonic mixing to produce homogeneously mixed nanoparticulate-epoxy composite of improved physical properties. Composites Part A 2011;42:1421-31.

[9] Matadi Boumbimba R, Wang K, Bahlouli N, Ahzi S, Rémond Y, Addiego F. Experimental investigation and micromechanical modeling of high strain rate compressive yield stress of a melt mixing polypropylene organoclay nanocomposites. Mech Mater 2012;52:58-68.

[10] Matadi Boumbimba R, Bouquey M, Muller R, Jourdainne L, Triki B, Hébraud P, et al. Dispersion and morphology of polypropylene nanocomposites: characterization based on a compact and flexible optical sensor. Polym Test 2012;31:800-9.

[11] Chen C, Justice RS, Schaefer DW, Baur JW. Highly dispersed nanosilica-epoxy resins with enhanced mechanical properties. Polymer 2008;49:3805-15.

[12] Ferreira JAM, Reis PNB, Costa JDM, Richardson MOW. Fatigue behaviour of Kevlar composites with nanoclay-filled epoxy resin. J Compos Mater 2013;47:1885-95.

[13] Gojny FH, Wichmann MHG, Fiedler B, Bauhofer W, Schulte K. Influence of nano-modification on the mechanical and electrical properties of conventional fibre-reinforced composites. Composites Part A 2005;36:1525-35.

[14] Hosur MV, Mohammed AA, Zainuddin S, Jeelani S. Processing of nanoclay filled sandwich composites and their response to low-velocity impact loading. Compos Struct 2008:82:101-16.

[15] Ávila AF, Carvalho MGR, Dias EC, da Cruz DTL. Nano-structured sandwich composites response to low-velocity impact. Compos Struct 2010;92:745-51.

[16] Bruzaud S, Bourmaud A. Thermal degradation and (nano)mechanical behavior of layered silicate reinforced poly(3-hydroxybutyrate-co-3-hydroxyvalerate) nanocomposites. Polym Test 2007;26:652-9.
[17] Yi F, Yu R, Zheng S, Li X. Nanostructured thermosets from epoxy and poly(2,2,2-trifluoroethyl acrylate)-block-poly(glycidyl methacrylate) diblock copolymer: demixing of reactive blocks and thermomechanical properties. Polymer 2011;52:5669-80.

[18] Arkema launches Nanostrength for advanced composite materials, Additives for Polymers, 2005, 2005, p. 3.

[19] Bashar MT, Sundararaj U, Mertiny P. Mode-I interlaminar fracture behaviour of nanoparticle modified epoxy/basalt fibre-reinforced laminates. Polym Test 2013;32:402-12.

[20] Denneulin S, Viot P, Leonardi F, Lataillade J-L. The influence of acrylate triblock copolymer embedded in matrix on composite structures' responses to lowvelocity impacts. Compos Struct 2012;94:1471-81.

[21] Tran TA, Leonardi F, Bourrigaud S, Gerard P, Derail C. All acrylic block copolymers based on poly (methyl methacrylate) and poly (butyl acrylate). A link between the physico-chemical properties and the mechanical behaviour on impact tests. Polym Test 2008;27:945-50.

[22] Yang X, Yi F, Xin Z, Zheng S. Morphology and mechanical properties of nanostructured blends of epoxy resin with poly( $\varepsilon$-caprolactone)-blockpoly(butadiene-co-acrylonitrile)-block-poly( $\varepsilon$-caprolactone) triblock copolymer. Polymer 2009;50:4089-100.

[23] Sarasini F, Tirillò J, Valente M, Valente T, Cioffi S, Iannace S, et al. Effect of basalt fiber hybridization on the impact behavior under low impact velocity of glass basalt woven fabric/epoxy resin composites. Composites Part A 2013;47:109-23.

[24] Sihn S, Kim RY, Huh W, Lee KH, Roy AK. Improvement of damage resistance in laminated composites with electrospun nano-interlayers. Compos Sci Technol 2008;68:673-83.

[25] Lankford J. Micromechanisms of compressive failure in a glass fibre-reinforced amorphous thermoplastic. J Mater Sci 1993;28:3027-34.

[26] Wang K, Matadi Boumbimba R, Bahlouli N, Muller R, Bouquey M, Ahzi S Dynamic compressive behavior of a melt mixed polypropylene/organoclay nanocomposites. J Eng Mater Technol 2011;134:010905.

[27] Reis PNB, Ferreira JAM, Zhang ZY, Benameur T, Richardson MOW. Impact response of Kevlar composites with nanoclay enhanced epoxy matrix. Composites Part B 2013;46:7-14.

[28] Taraghi I, Fereidoon A, Taheri-Behrooz F. Low-velocity impact response of woven Kevlar/epoxy laminated composites reinforced with multi-walled carbon nanotubes at ambient and low temperatures. Mater Des 2014;53: $152-8$.

[29] Soliman EM, Sheyka MP, Taha MR. Low-velocity impact of thin woven carbon fabric composites incorporating multi-walled carbon nanotubes. Int J Impact Eng 2012;47:39-47. 